Zarifa G. Jabrayilova

Institute of Information Technology, ANAS, Baku, Azerbaijan

DOI: 10.25045/jpis.v06.i2.03

depart15@iit.ab.az

\title{
PROBLEMS OF PROTECTION OF PERSONAL DATA IN HUMAN RESOURCE MANAGEMENT SYSTEMS
}

The article describes the nature of employees' personal data in human resource management systems and reviews protection and security issues. These systems are important in an organisation's personnel management because of the threat of workers' personal data being disclosed. The purpose of the study is to analyse the experience of developed countries in the areas of protection and security of workers' personal data and legislation related to that topic. The best practices in the protection of workers' personal data in the labour legislation of the Republic of Azerbaijan indicate the necessity of appropriate development of regulations within any organisation.

Keywords: human resources management systems, workers' personal data, protection of workers' personal data, legislative norms regulating workers' personal data.

\section{Introduction}

In the 1960s, Drucker, who developed the management theory of intelligent labour, began to form a theory on the innovative economy. The theory is based on new ideas about the information society which is characterised by constant changes. According to Drucker, a combination of information technology and human resources capabilities will lead to the emergence of the global system for management support and define the key competitive advantage of a company in the twenty-first century (Figure 1) [1].

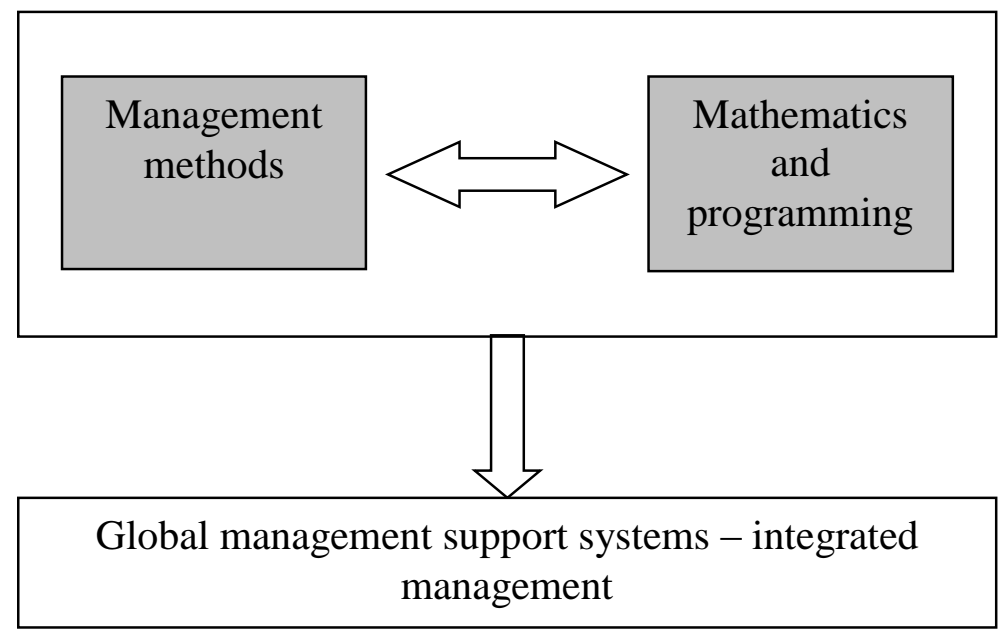

Figure 1. Global management support systems - future information-management

The HRM system is an example of the realisation of this idea. There are many software products at the intersection of HRM issues and information technology. This system supports all the elements of human resource management, such as recruitment, planning, training, assessment, positioning and re-positioning and motivation, although it was meant for accounting and payroll only when it was first developed [2, 3]. For example, SAP (founded in 1972, Germany, annual turnover of more than 14 billion), Gartner (USA), BAAN (founded in the Netherlands in 2003), Scala (founded in 1978, Sweden), Navision (founded in 1983, Denmark, currently used in Norway, Germany, Spain, England, the US), and etc. [4-8]. 
Russia develops a number of new software products that take into account the specific features of the local conditions, for example, "Босс-кадровик", "1C", "Парус", "Галактика", "Бэсм-Про". These products can be divided into the following groups: "Инфин" package, "ИнфоСофт" package, "Галактика" corporation personnel system, "Управление персоналом" module of "Интертраст" company, "Зарплата и кадры" module of "1C" Company, accounting system of "Пapyc" company on personnel, labor and wages, Oracle HR system of "SAP R/3"company, Управление персоналом system of "АиТ СОФТ" Company, Персонал system of Борлас Ай-Би-Си Company, Босс-Кадровик system, and etc. [9].

The globalisation process and the development of high technologies have changed perspectives on relations with the personnel. The solution of each HRM issues requires new conceptual approaches to the regulation of personnel relations and the development of scientifically substantiated methods. HRM's effectiveness depends on a person's managerial competence (i.e., knowledge, professional skills, personal and behavioural qualities, intellectual and professional qualities). HRM focusses on supporting the business strategy of the organisation in the context of improving the features and role of human participation [10-12]. Intelligent technologies are currently being used to develop HRM decision support systems for personnel planning, recruitment and admission, dismissal and promotion [13-15]. However, confidentiality problems and personal data protection in these systems still remains a pressing issue.

\section{Personal data security and the confidentiality of workers}

The efficient use of HRM systems requires organisational support (supporting personnel, developing new corporate organisational rules, training personnel, etc.), and it necessitates the confidentiality and protection of data about employees that may cause material and moral harm if leaked. To appreciate the significance of the situation, an article on the official website of the European Commission on the "Protection of Workers' Personal Data" states that in the areas where personal data is stored and information technology is used, the organisation of labour shall be strengthened and expanded. Otherwise, the gap between work and personal life will expand [16].

International experience shows that one of the main obstacles to the development of HRM systems is the issue of ensuring the confidentiality and safety of workers' personal data [16, 17]. Thus, any organisation with access to the data of its employees should guarantee the safety and confidentiality of the information. Any information about any employee, regardless of where it is stored, should be confidential. Employees' confidential data should be given to a third party by the authorised person within the enterprise (the employer) only with the consent of the worker [18].

The protection and information security of employees' personal data is regulated by ISO 77799 , adopted in 2000 [19]. The standard is based on the BS 7799 standard for "the practical rules of information security control" adopted in 1995 in the UK. According to this standard, information security includes the following:

- At the organisational (administrative and procedural) level, the goal set by the organisation and its security policy to achieve this goal;

- At the procedural level, the development and implementation of physical protection measures and information security guidelines for personnel;

- At the technical (hardware and software) level, the implementation of tested and certified decisions; standard countermeasures such as backups, password and anti-virus protection, firewalls, data encryption and so on.

The ISO 27002 standard was developed in 2013 based on ISO 77799 standards. The ISO 27002 standard includes "the guidelines and principles of information security management, implementation, maintenance and development within the organisation". For the first time, the standard specifies security issues in certain areas (e.g., health care, manufacturing, etc.), and consists of 14 control sections, which covers 114 standard elements [20]. The sections include security policies of the organisation, the organisation of information security, human resources 
security, physical security, communication control, and control of entries, information systems acquisition, improvement, and maintenance.

The main audit areas include examining available security policies, standards, guidelines and procedures; detecting existing security gaps and risks; and recommendations for safety improvements. Security audits should be conducted periodically to ensure compliance with security policy and to reduce the risks [21].

The main objectives of the audit of personnel records are described in [22] and include compliance with "regulations on the protection of the workers' personal data", that is, a normative act of the company.

\section{The character of the workers' personal data in HRM systems}

The workers' personal data is the information, facts, events and situations that identify a specific employee and are necessary for the employer to establish labour relations with him/her [17].

HRM systems should ideally provide the following:

- storing professional archives for each employee;

- multiple (multi-criteria) candidates for vacancies;

- certification of personnel, taking into account testing methods;

- ranking personnel;

- evaluation of employees' performance (including management staff).

Such a system allows a company:

- to detect negative circumstances in the company;

- to control expenses for personnel training;

- to assess motivation;

- to develop motivation mechanisms to increase employees' interest;

- to develop a modern recruitment system;

- optimal placement of personnel;

- to design the company's new staff structure;

- to analyse quantitative and qualitative parameters of the personnel.

HRM systems contain the modules to support decisions regarding staff selection, recruitment, the evaluation of employees' performance, position compatibility, and building internal recourses for promotion, rewards, training and motivation [23]. All of these are provided by accessing the workers' personal data according to the company's need. For example, the personal information characterising employees includes [23, 24] demographic information (sex, age, place of residence, marital status, etc.); education (secondary, higher education, certification); experience (experienced in this position, worked in related positions, and worked in the profession related to this position, or no experience); specific skills (computer skills, language skills, driving ability, athletic ability, etc.); personal qualities (motivated, isolated, sociable, etc.);health (fully healthy, having a certain disease, having psychological problems, etc.).

Sometimes testing is used to define these criteria. According to the Society for Human Resource Management (SHRM), in 2010, 68\% of organisations used tests in the recruitment of workers [25]. The following tests are used to determine a person's psychological state: Socionics Duality Descriptions by Ovcharova and Meged; the psycho-geometric test of personality; and the Luscher test [26, 27].

Socionics Duality Descriptions specifies16 types of people (e.g., Don Quixote is a seeker, Dumas is a mediator, and Hugo is an enthusiast). The psycho-geometric test of personality determines the level of thinking. The Luscher test identifies the applicant's qualities in terms of being hard-working, under stress and able to adapt to conditions.

The Sixteen Personality Factor Questionnaire by Cattell defines personal qualities [26] according to the following measures: intelligence; a range from closed to sociable; emotional to calm; 
conformable to dominant; tactful to emotional; submissive or courageous; brutish or sensitive; naive to sceptical; open and diplomatic; self-confident or hesitant; conservative to radical; boring to having energy; self-controlling; dull and nervous.

Personal data on employees' professional activity is collected in the HRM system, including the following items:

- Vital facts, events;

- Military registration;

- Social privileges;

- Imprisonment;

- Bills provided to tax inspection;

- Re-qualification and retraining;

- Attestation results;

- Service inspections;

- Health;

- Medical examination to be competent to fulfil duties.

Therefore, the protection of the workers' data stored in such systems is of great importance.

\section{Legal documents for the protection of workers' personal data}

The Personal Data Privacy and Security Act of 2014 [28] adopted in the $113^{\text {th }}$ Congress of the United States intercepts seizures of personal information, provides for confidentiality, and boosts the duties of law enforcement bodies to prevent unauthorised access to data. For the first time, the Act applies the penalty of five years' imprisonment for those who deliberately violate the security of personal information.

In Brazil, new amendments made to the law on the protection of personal information in 2015 strengthen the responsibilities of companies and individuals engaged in the automated processing of personal information. The law includes fees and strict penalties for errors in processing of personal information.

Two directives of the EU on the protection of personal information relate to employees. The first one concerns the protection of personal information when processing and transmitting it, and the other one protects personal information from unauthorised access in personal data processing and in the electronic communication sector [30]. There are regulations in the legislation of EU member states regarding these directives and certain international norms. These directives state: “...the employees' personal information is collected before setting up labour relationships. This goes on until he is hired and this information can be spread before his hiring. The certain regulations have to be available to reflect the protection of the candidate's personal information" [30].

In Chapter 14 of the Labour Code of Azerbaijan, important organisational, physical and technical (hardware) measures are applied to protect personal information from unauthorised and accidental access, destruction, changes and copying. According to Paragraph 86/13 of the Labour Code, the security of personal information is provided by the protection of personal information including tools such as encryption, prevention of unauthorised access and the spread of information through technical channels. The methods and tools of protecting employees' personal information from unauthorised access (Article 86/14) consider locating the processing hardware of personal information in a guarded location; ensuring the physical security of processing hardware used for personal information; and ensuring protection of such information systems from hazards such as viruses. 
The person accused of violating the rules regulating the security and processing of employees' personal information (Article 90) may bear criminal, civil, administrative or disciplinary responsibility according to federal laws.

These articles of the Labour Code generate the basic principles of local normative acts of various organisations in the regulation about the protection of employees' personal information. The legislation guarantees the protection of employees' personal information and requires the existence of regulations covering the processing of employees' personal information and its use in each organisation. following:

Taking into account the specifics of each organisation, these regulations define the

- Objectives of regulation

- Contents of employees' personal information

- Duties of employer

- Duties of employee

- Rights of employee

- Collecting, processing and saving personal information

- Transmitting personal information(personal information of an employee can be received from a third party only with the consent of the employee)

- Accessibility of personal information (internal and external access, accessibility of relatives and family members)

- Protection of employees' personal information (information security methods, organisational security measures)

- Responsibility for spreading personal information.

The regulation about the protection the personal information of employees is compatible to ISO 27002 standards guaranteeing the security and protection of personal information of employees at the organisational, procedural and technical (hardware) level, taking into account the specifics of each organisation.

\section{Legal and regulatory documents on the protection of workers' personal data in Azerbaijan}

The protection of personal data, including protection of workers' personal data in Azerbaijan, is regulated by the UN Declaration on Human Rights adopted at the General Assembly on December 10, 1948, and in Article 32 of the Constitution of the Republic of Azerbaijan, and the laws on "information, informatisation and protection of information", "information freedom" and "personal information".

Article 32 of the Constitution of the Republic of Azerbaijan on the Right to Personal Security states: "Gaining, storing, use and spreading information about a person's private life without his/her consent is not permitted" [35].

Chapter 5 of the Law on "information, informatisation and protection of information" of the Republic of Azerbaijan is entitled "Protection of Information" and consists of the following four Articles [36]:

Article 17. Objectives of Protection in the Field of Information Resources and Processes.

Article 18. Organization of Information Protection.

Article 19. Rights and Duties of Subjects in the Field of Information Protection.

Article 20. Protection of Subjects' Rights in the Sphere of Informatization.

Clause 11.15 of the Law of the Republic of Azerbaijan on freedom of information states that "the secrets about the private life of citizens (personal information)" is referred to as information with limited access" (Article 11) [37].

The Law of the Republic of Azerbaijan on personal information consists of five chapters and contains general provisions; categories of personal data, and regulation of their collection, design and protection; the rights of the subject; collection and processing of personal 
information; and state regulations on collection, processing, and protection of personal information [38]. This law is also applied to the protection of workers' personal data, and in this respect, these elements should be taken into account in the present labour legislation. Nevertheless, the Labour Code the Republic of Azerbaijan does not include any article to protect workers' personal information [39]. However, the organisations may establish a unified legal framework for the protection and security of workers' information in HRM systems, and to develop regulations on the protection of workers' personal data. One of the aspects requiring regulation is accounting and regulatory audits in Azerbaijan to comply with the "regulations on the protection of workers' personal data" as a normative act.

\section{Conclusion}

Rapid development of HRM systems and the expansion and growth of personal data processing with computer technology have led to issues related to information security and protection. Securing employees' personal data and protecting it from undesirable access should be based on new innovative approaches. Ensuring employees' privacy and confidentiality requires the strengthening of organisational, technological and legal measures in accordance with the ISO 27002 standard, taking into account the specifics of each organisation.

In addition to the success achieved in Electronic Azerbaijan, a wide range of applications and the development of HRM systems have included certain measures that address the security of personal data, which first requires the "regulations on the protection of workers" personal data" to be established as a normative act of each organisation. This regulation includes the following:

- general requirements to be followed by the employer (and its representatives) to ensure the rights and freedom of the workers when collecting and processing their personal data;

- organisational and technical measures to protect the workers' personal data from unauthorised access, destruction, amendments, blocking and backup;

- methods and techniques to protect unauthorised access to workers' personal data;

- disciplinary, administrative, civil or criminal liability for violation of the provisions regulating the protection and processing of workers' personal data.

The articles related to the protection of workers' personal data shall be introduced to the Labour Code of the Republic of Azerbaijan to develop the legal basis of the regulations.

\section{References}

1. P.Drucker, Management challenges for the 21st century http://www.klex.ru/8eq

2. Leon A. ERP Demystified Copyright, 2007, 585 p.

http://www.books.google.ru/books?id=8kBfQPvWvSMC\&hl=ru\&source=gbs_similarbooks

3. Becker BA, HuselidMA. \& UlrichDThe HR scorecard. Massachusetts: Harvard Business Scholl Press, 2001, p235.

4. http://www.sap.com

5. http://www.gartner.com

6. http://www.ucg.com.ua/erp_scala.html

7. http://www.navisioninfo.com

8. http://www.erp.galaktika.ru

9. Human Resource Management: Lectures, N.V.Kislyak; edited by L.I.Voroninoy; Urals Institute of Public Administration and Entrepreneurship. Gos.Universiteta, Ekatirinburg 2007, pp. 91.

10. Cole GA Personnel and Human Resource Management. Wadsworth: Thomson Learning, 5 edition, 2002, $448 \mathrm{p}$.

11. Spencer and Spencer SMCompetence LM models for superior performance at work. Wiley India Pvt. Limited, 2008, 384 p. 
12. M. Armstrong Armstrong's handbook of human resource management strategies, 10th ed. London: Kogan Page, 2006, 216p.

13. Polychroniou PV, Giannikos I. Methodology A fuzzy multicriteria decision-making in human resources for a selection of Greek private bank // Career Development International, 2009, vol14, no4, pp372387.

14. Kelemenis A., Ergazakis K., D. Askounis Support managers' selection using an extension of fuzzy TOPSIS // Expert Systems with Applications, 2011, vol.3, no 38, pp27742782.

15. Jabrailova ZG, Nobari Sh.M. Using Fuzzy Decision Support Systems in Human Resource Management / International IPCSIT Proceedings of Computer Science and Information Technology, 2012, vol. 36, IACSIT Press, Singapore, pp217220.

16. http://www.ec.europa.eu/social/main.jsp?catId=708

17. Labor Code of the Russian Federation,

1. consultant.ru/popular/tkrf/14_18.html\#p1884

18. Federal Law on "Personal Data" dated 27 July 2006, http: wwbasegarantru12148567ixzz3Y7vprE7H

19. http://www.praxiom.com/iso-17799-2000.htm

20. http://www.27000.org/iso-27002.htm

21. Security risk assessment and audit guidelines, September 2012 http://www.ogcio.gov.hk/en/information_security/policy_and_guidelines/doc/g51_pub.pdf

22. HR accounting audit, http://www.cacs.az/kadrlar-auditi

23. Jabrayilova Z.G., Nobari S.M. Simulation of the process of selecting candidates for vacant positions using fuzzy logic/Artificial Intelligence, 2009, № 1, pp.238-243.

24. Makarov I.K. Human Resource Management. Five lessons of effective HR-management. M.: Case. 2007, pp. 232.

25. http://www.shrm.org/about/pages/default.aspx, available on 19.05.2010

26. Encyclopedia of psychological tests. Personality, motivation, and requirements. M .: AST Publishing, 1997. pp.300.

27. http://www.vsetesti.ru/356/

28. Personal Data Privacy and Security Act of 2014, http://www.congress.gov/bill/113thcongress/senate-bill/1897

29. http://www.huntonprivacyblog.com/2015/02/06/brazil-releases-draft-personal-dataprotection-bill

30. Protection of workers' personal data in the European Union, Manuscript completed in July 2002, $121 \mathrm{p}$.

31. Constitution of the Russian Federation: www.constitution.ru

32. http://www.kursktelecom.ru/licenses_pdf/guard_person_dannyx_ktk.pdf

33. http://www.appm.ru/documents/personaldata.php

34. http://muzgorbol.ru/polozhenie-ob-obrabotke-i-zaschite

35. The Constitution of the Republic of Azerbaijan, http://www.azerbaijan.az/portal/General/Constitution/doc/constitution_a.pdf

36. Law on the "Information, informatisation and protection of information" of the Republic of Azerbaijan, http://www.wipo.int/edocs/lexdocs/laws/az/az/az018az.pdf

37. Law on the "Freedom of information", http: wwwictazazcontent112

38. http://www.dmx.gov.az/userfiles/files/ferdimelumatlarqanun3.pdf

39. Labour Code of the Republic of Azerbaijan, http: www.eqanun.az/code/7 